\title{
Learning Collaboration in Home Care Service
}

\author{
Margaretha Herrman $^{1 *}$, Lena Nilsson ${ }^{2}$ \\ ${ }^{1}$ University West, Department of Health Sciences, Trollhättan Sweden \\ ${ }^{2}$ University West, Social and Behavioral Studies, Trollhättan Sweden
}

*Corresponding Author: Margaretha Herrman, University West, Department of Health Sciences, Trollhättan Sweden

\begin{abstract}
Since the 1990s, the municipalities in Sweden have been more restrictive in their allocation of relief in elderly care, for example cutting the times granted for home care. Elderly care hasbeen streamlined in ways that force the staff to take care of increasing numbers of clients with extensive and complex needs. To compensate for the restrictions a value system has been implemented to improve care quality.
\end{abstract}

The purpose of this project was to study the implementation of the value system and to promote knowledge among home care staff, in order to allow the structures and conditions for care provision to be questioned and developed. After an introduction to qualitative research methods staff interviewed elderly people receiving home care. The results were analyzed through dialogue and interaction between researchers and practitioners.

Staff awareness of their own skills and the complexity of their work increased significantly. They concluded overall that increased resources are needed in order to achieve the national value system goals and to comply with the rehabilitative and independent-living approach of the Social Services Act. While the value system itself is an expression of the human rights of older people, enforcing it may conflict with the provisions of the Work Environment Act concerning working conditions. The work-integrated learning (WIL) profile at UW focuses on the practical integration of learning into the world of work and the interface between learning and application. This project, as an example of learning within an organization, fits the profile.

Key words: Elderly care, home care staff, work integrated learning (WIL), action research, reflective learning, home care development

\section{INTRODUCTION}

Since 2012, Sweden has had a national value system for elderly care, described by the National Board of Health and Welfare (2006) as follows: "The national basic principles for care of the elderly apply to all municipalities and activities performed in relation to elderly care under the Social Services Act. The care provided for elderly people by the social services should be aimed at affording thema dignified life and a sense well-being" (Chapter 4, 4§ Social Services Act 2001, p. 453).

In order to achieve this, care for the elderly needs, among other things, to protect and respect the individual's right to privacy and physical integrity, self-determination, participation and individuality(National Board of Health and Welfare, 2012). The National Board of Health and Welfare has developed guidelines that provide advice about how to apply the basic principles according to ethical values and norms in order to underpin an activity. The national value system should lead to the staff who work with the elderly being equipped to support each elderly person according to their individual wishes and qualities. The value system should permeate the entire range of care of the elderly regarding treatment and implementation. It serves to elucidate values, and can be seen as providing an ethical approach and acting as a support. However, it also needs to be understandable, showing what the focus should be in everyday work, in practical terms, concerning ideas and actions. (The National Board of Health and Welfare, 2012). The basic principles are stated using the following terms: self-determination, security, meaningfulness and context, respect for 
privacy and personal integrity, individualization and participation; efforts to achieve good performance and good quality are seen as encapsulating the value system.

The National Board of Health and Welfare wants the work with elderly care to be evaluated, prompting municipalities to focus on the results of educational efforts and to examine the ways in which the quality of care has improved, raising the question of how performance is to be examined and assessed. These questions were presented to us as researchers, and after discussions with municipal home care management, we were able to initiate an interactive research project. The project was carried out together with forty home care employees with whom we worked for more than two years to jointly describe and investigate the practice and value-based quality of home care. This article concerns a way of working together interactively with home care staff and presents our joint results. The work concluded with a comprehensive report in which staff themselves both described how to work with the value system and reflected on their own work.

University west has a work-integrated learning (WIL) academic profile focusing on the interface between learning and its application to the world of work. The integration of value system learning with the practicalities of work constitutes an illustrative example of learning within an organization.

\subsection{Swedish Home Care}

The care of older people has been a social responsibility since the mid-20th century, but despite the fact that society has the legal responsibility in practice the work is largely carried out by relatives (Szebehely, 2011). Since the 1990s, the municipalities have allocated relief efforts in the care of the elderly and home care more restrictively; the time for granted relief has been reduced, for example. This is partly a reflection of the crisis in state finances which led to cuts in municipal resources at the same time that costs for elderly care were increasing (Hjalmarsson, 2014). Despite the more limited resources, the policy goals for elderly care have not changed. Thorslund (2010) highlights that elderly care has been trimmed and streamlined to allow staff to take care of increasing numbers of elderly people with extensive and complex needs.

Home care service managers, directed by decisions regarding the aid granted, guide the home care workers as to what each user is entitled to receive. The municipalities have local guidelines for assessing applications for assistance. People granted home services have the opportunity to choose a provider and can replace them if they are dissatisfied with the service. The municipalities must have an option available for those who do not wish or are unable to choose a provider.

The work in home care covers a wide range, including domestic tasks, shopping, nursing and delegated medical tasks. While care activities are of a practical nature, care is also relational (Bennich, 2012). Personal knowledge and personal relationships are important for care work to function properly (Edebalket al.1995). Bennich (2012) states that elderly care, perhaps more than other humancare activities, is dependent on personal relationships-changing the care staff changes the care effort. Those who work in home care are trained nurses or nursing assistants and predominantly women and the average age is high (Hjalmarsson, 2014).A literature review(National Board of Health and Welfare, 2006)shows that staff in elderly and home care have to be able to carry out five different types of work - care tasks, social tasks, household tasks, medical tasks and administrative tasks (2006:14). "These tasks have different values for nursing staff and the most important, and the very essence of the work, are the care services. The nursing staff believe that the management underrate the social tasks which include both knowledge and skills such as taking the time to talk to the client, go for a walk or activate them or making contact with relatives, dentists, doctors or hairdressers. The staff are the link between the unit and the outside world. The lack of time to carry out social tasks leads to stress among the nursing staff "(2006: 14-15).

Hjalmarsson (2014) summarizes the terms of employment for care and care staff pointing out that the work of home care staffis often characterized by a high pace and little influence over the work. The home care providers cannot influence the time calculated for the work, nor the hourly rate. The tasks today are significantly more qualified than before, and involve home care, nursing and medical tasks. This means that the staff should be qualified and able to adapt their efforts to the situation.

In recent years, much research has been doneon home care. Hjalmarsson (2014) and Sörensdotter (2008), for example, have both conducted research closely related to elderly care. It is not so common, 
however, for the staff themselves to participate as co-researchers, as they did in our project. The only similar example we found is at Södertörn University, where staff in elderly care wrote about and reflected on their work (Alsterdal, 2009).

\section{INTERACTIVE RESEARCH}

Traditional research should be supplemented in collaboration with participants, according to Bennich (2012). Research collaboration offers opportunities for developing both theoretical and practical knowledge in association with practitioners within an organization. Through dialogue and interaction between researchers and practitioners (development of practical knowledge) advancement is possible and the results can be used directly. Holmquist (2015) advocates a supportive collaboration approach and has developed an experience-based understanding of knowledge where practitioners are involved in the research process and have the opportunity to influence the outcome, thus becoming coproducers of knowledge. We have a similar ambition to combine theoretical and practical questions in order to contribute to a local theory, a theory in action. The practitioners need to be acquainted with the researchers' knowledge in order to obtain the tools needed to change their own reality. According to Holmquist (2015) this means the following: 1) Practitioners become acquainted with academic knowledge through researchers (acquiring knowledge), 2) the researchers contribute to developing the latent knowledge of the practitioners (developing their own knowledge) and 3) practitioners and researchers co-operate in the social production of knowledge (common knowledge production).

Holmquist (2015) also highlights abductive interactivity, i.e. an interaction between research and practice bringing awareness of new contexts, to interpret meaning, to perceive new relationships, to explain relationships and to give meaning to what is already known. Such an approach comes close to Kemmis' definition, with reference to Kurt Lewin from the 1940s, that "action research consisted in analysis, fact finding, conceptualization, planning, execution, more fact finding or evaluation, and then a repetition of this whole cycle of activities"(Kemmis, 1980: 4).

Specifically, this means that practitioners participated in all the research activities, from planning to distribution of the report in which they summarize the part they playedand the results of their research efforts. In our project the home care staff were continuously involved in discussions of the research questions. Together we also formulated various dimensions of staff skills.Working in dialogue with the staff in this way means thatall co-producers become knowledgeable. Conversations and reflectionsallowed us to take advantage of each other's experience - the expert knowledge of the staff as nurses or nurse assistants, the elderly'sexperience of receiving care and our academic expertise.

\section{AIMS AND ISSUES}

The aim of the project was partly to develop knowledge and skills among the staff and to increase their awareness of the basic values underpinning their work, and partly to question and develop the structures and conditions within the care provided. Kemmis (2006) points out that there are two types of results in interactive research; learning and the opportunity for development, which requires a critical review of the results. Learning is the outcome of a reflection process where one gradually becomes aware of the skills involved and the limitations of the work. The awareness of limitations can lead to the second type of result in interactive research: envisaging structural causes of the shortcomings in the work. Holmquist (2015) advocates a supportive collaborative approach with an experience-based understanding of knowledge, where practitioners are involved in the research process, have opportunities to influence it and thus become co-producers of knowledge.

The collaboration with home care practitioners is intended to develop sustainable structures by problematizing concepts, using awareness-raising approaches and having the staff review their own practices. The development of practical knowledge in this process is expected to lead to proposals for new ways of working or to new structures to improve the quality of care and of the work environment. By utilizing experience and existing knowledge, new knowledgeiscreated(Nilsson \& Herrman, 2012). The practitioners participate as co-researchers and, together with the academic researchers, they examine the conditions, value system, feasible working methods, skills needed etc. Research collaboration involves not only follow-up studies (Stigendahl, 2011) but also developing the endeavor further together with practitioners, based on a firm knowledge of the whole undertaking from the definition of the problems to the analysis and dissemination of results. Svensson et al. (2002) arguethe need for interactive research in areas where practical and theoretical knowledge develop in a 
reciprocal process. Such a process requires time, continuity, resources and commitment from coresearchers (Bennich, 2012).

The article's empirical data comprise notes taken during work-place meetings, and those written after the end of each meeting. We did not use a tape recorder as on most occasions two researchers were present and could compare recollections shortly after the meetings. There were also ongoing opportunities to address uncertainties and concerns with both unit managers and working groups.

\section{RESUlts AND ANAlysis. ReSEARCHCOLLABORATION-A LEARNING OUTCOME}

Our contribution to academic knowledge from the working with the home care staff concerns both qualitative methods and the wording of the expressions the staff use when they describe their work and events in practice. According to Holmquist (2015), the knowledge of practitioners gives space for new contexts, interpreting meaning, and perceiving new relationships. Together we designed a research process; initially there was uncertainty and doubt but gradually this shifted into curiosity, confidence and enthusiasm. We worked in dialogue with the staff in such a way thatall co-producers became knowledgeable. We shared each other's experiences in discussions and reflections - the staff contributed their skills, the elderly contributed their experiences through the interviews conducted by the home care staff and we contributed our academic skills.

The workflow was based on the monthly meetings between us and the approximately 40 employees in the home care service. The staff were divided into three working groups which we met on separate occasions during the same week. On specific occasions, when the aim was to gather the staff for some educational purpose, we gave lectures on qualitative methods, content analysis and report writing, mainly because they wanted to know how to conduct interviews, how to analyze them and how to write for a larger public. Finally, we also had continuous contact with a smaller group who compiled the material. The initial meetings were held to gain an insight into the work of the home care service and were based on conversations about what the staff perceived as essential and how their routines related to value system work. These meetings gave the academic researchers the opportunity to present considerations and ideas about how to contribute to developing the home care services. The initial discussions led to the choice of interviewing elderly users as a model for accessing users' views concerning care and care qualities. The staff received information about qualitative methodology, interviewing as a method and research ethics and they themselves then decided which elderly people to interview. In cooperation with the researchers, they designed interview questions and follow-up letters.

We had the opportunity throughout the interview period, through continuous access to the transcribed interviews, to deepen conversations about the impact of working conditions, values, users' views, decisions and service plans on the possibilities for continuity and quality. We also introduced content analysis which they then applied to the interview material. Smaller writing groups agreed to compile the results into a coherent written text. In addition, we suggested that employees could contribute short stories about common events during a working day. A dozen people wrote such stories and they were included in a separate chapter. The staff made careful and correct preparation for the conduct and analysis of the interviews and the writing up of their results. They took ethical concerns into consideration and showed great sensitivity during the interviews and in the narration of events/stories from their work.

What emerged clearly during the project is that the staff want to be even better at meeting the needs of the elderly, i.e. they want to enhance the quality of their work. The staff thought that awareness of the national value system could help them to achieve this. There are studies which indicate that caregivers are often satisfied with their situation, but they also want to deepen and broaden their knowledge, i.e. they want horizontal development. There are studies showing that caregivers in a supportive learning environment, as opposed to those in workplaces without, focus more on the users' need for self-help and rehabilitation efforts (Ellström et al., 2008). However, gaining knowledge about work development requires reflection and the questioning of invasive routines and behavior patterns, and that the individual is motivated and understands that experience is important in the learning process (Ellström, Ekholm and Ellström, 2003). Such motivation is clearamong the staff. Birge Rönnerfelt and Norman (2015)refer to the Reflex project (Gothenburg), where staff working with the elderly received this kind of training. Their results show the trial of alternative work methods became part of the home care work and that priority was given to proper workplace tasks. An additional positive "by-effect" 
was that the number of long-term healthy people was significantly higher than before the project started (2015: 17). To gather the staff for recurring reflection seminars, in addition to daily work, can provide many benefits at both individual and group levels. Acting as a learning organization, that acquires, develops and implements familiarization knowledge (practical knowledge) with professional knowledge, offers just such profit and opportunity (Birge Rönnerfeldt, 2015).

According to the National Board of Health and Welfare (2013), every fourth employee in elderly care lacksa relevant education despite recommendations that those who work in healthcare must be educated toupper-secondary school level. The Board has issued general advice regarding the basic knowledge required of staff working in care of the elderly provided by the social services (SOFS 2011: 12). The report: In the service of the elderly, the Senior Assistant (SOU, 2008), states that there is a need to describe, clarify and develop: "The very complex knowledge and skills that the basic staff in elderly care have and which care and nursing of the elderly requires" (2008:126). According to the report, staff in the care sector need a combination of professional skills and a professional approach. It also emphasizes the importance of the contribution of basic skills to improving quality and efficiency and the importance of good treatment as an aspect of quality. The report also expresses concern about future recruitment for home care services.

The staff's awareness of their own skills and the complexity of their work has increased significantly over the course of the project. Not that the staff did not understand this before, but they have revealed it more clearly to themselves. The staff group has extensive knowledge that not only relates to facts and insights about contexts and meanings but also to familiarity, judgement and experience, i.e. good professional skills. The discussions conducted in the working groups meant sharing knowledge with each other - theoretical knowledge and practical knowledge, reflecting and learning from each other. Ways to improve health among the elderly was a recurring topic in the discussions.

The staff's general conclusion is that increased resources are needed for the care of the elderly if the goals of the national value system are to be achieved. As a third party, we can only agree, for several reasons, primarily relating to the staff's work situation and the conditions of the elderly in society. The home-based multifaceted activity described by home care staff resemblesa difficult puzzle where the pieces do not fit together. The fact that home carestill functions, which it does, is largely due to the great efforts made by the staff - and to some extent to their awareness that elderly people are entitled to receive the care that the value system dictates. The elderly seem to be generally satisfied butit is open to question how representative those elderly people interviewed by the staff are, compared to the group of elderly as a whole. The healthiest of the elderly were chosen for interview and the interview situations described by the staff were very positive; the elderly appreciated the opportunity to be listened to and the possibility of sharing their views. They also understood the interview was a way of participating in development work. The elderly told the staff that they appreciated their efforts but at the same time they expressed dissatisfaction with the "system" which stressed the staff and also prevented all their needs being met. This shows an important point of intersection between satisfied elderly clients and home care conditions. The satisfaction of the elderly seems to be come at the expense of the staff's working conditions. The staff do everything to avoid making their stress obvious; they avoid watching the clock, perform tasks calmly and communicate while they are doing various chores. They rush from one client to the next sometimes on a schedule that allows them no time; they help each other when extra efforts, such as lifting, extra care or other things, are needed. They are constantly prepared to squeeze the schedule in order to make one more extra effort. This cannot bethe best point of departure for future home care and elderly care. The number and proportion of elderly people in society continues to increase while interest in working in home and elderly care seems to decrease.

\section{CONCLUSION}

To undertake a two-year project requires, of course, both time and financial resources. We have met the staff mainly during workplace meetings and training days. The staffwere given some extra time to conduct interviews and compile the report. However, we want to emphasize that we are well aware that the staff wrote up parts of the projectin their spare time, after thehoursspent doing a much needed but physically and mentally hard job.

The elderly's perception of assistance is usually measured using standard questionnaires. In this project, the elderly were interviewed, on what we perceived were terms that were as equal as possible. 
This produces a more comprehensive and different input, which gives the elderly the opportunity to formulate their experiences and requests while allowing staff to reflect on their answers. It provides a better starting point for real change, if society is listening.

The report entitled In the Service of the Elderly(SOU 2008:126)mentions different areas of competence for future care, based on the value system; communication, laws and regulations, healthy aging, aging associated diseases, mental retardation, emotional and social care, physical care, meal/diet/nutrition, end-of-life care and medical care. These areas concern values and approaches, communication, social and emotional care, i.e. competencies considered important for providing high quality care. The need for better educated staff expressed by the community coincides with the home service staff's own requirements for skills development and a higher status for home and elderly care. One way to develop quality in home care work may be to raise awareness of relational skills and to contribute to the ability of the elderly to learn and retain everyday life skills. Resources to meet the need for supportive learning and rehabilitation have to be in place before shortcomings among the elderly manifest themselves. Such topics were on the agenda several times in the group discussions as, for example, was the emphasis on the time and resources needed by the elderly to be able to cope with certain everyday chores on their own. The staff is keen for the elderly to do this and they understand that it is part of their work to support and encourage elderly people to retain their abilities, that is, to increase participation, self-determination and meaningfulness. They express the need for a salutogenic approach and encourage empowerment. Such efforts are supported by the educational tool Senior Alert. The Social Services Act supports /requires an approach that preserves function, is rehabilitative and is also applied to relational aspects. Quality arises out of the meeting between staff and the elderly. The guidelines point out that supporting the elderly to make use of their self-determination is an educational task.

The value system is a policy imposed from above, (Lindberg, 2016) and is considered to be a tool for streamlining and improving the quality of an activity that has been criticized (National Board of Health and Welfare 2012). While the value system itself is an expression of the human rights of older people, enforcing it can conflict with the conditions under which the staff work. The home of the elderly person is also a workplace where the right to rest and to a good working environment is laid down in other legislation, such as the Work Environment Act with its various regulations (AML 1977/2014). The way the home care district has chosen to develop and regulate work in home care is an example of how value system work can be conflicted with work environment issues. This implies reflective workplace learning, a significant increase in home-based democratization and a way of utilizing the skills of the staff.

\section{REFERENCES}

[1] Alsterdahl, L. (2009) Vad är praktisk kunskap? [What is practical knowledge?] I: Svenaeus, F. \&Bornemark. (Ed.) Vad är kunskap? [What is practical knowledge?] Södertörn: Södertörns högskola, Institutionen för kultur och kommunikation, Centrum för praktisk kunskap [Södertörn University College, Departmentof Culture and Communication, Center for Practical Knowledge]

[2] AML (1977/2014). Arbetsmiljölagen [WorkEnvironment Act] http://www.riksdagen.se/sv/dokumentlagar/dokument/svensk-forfattningssamling/arbetsmiljolag-19771160_sfs-1977-1160

[3] Bennich, M. (2012). Kompetens och kompetensutveckling i omsorgsarbete. Synen på kompetens och lärande - i spänningsfältet mellan samhälleliga förutsättningar och organisatoriska villkor. [Competence and competence development in care work. The view of competence and learning - in the tension field between social conditions and organizational conditions]. Linköping: Linköpings Universitet, Filosofiska fakulteten Studies in Arts and Science No. 563.

[4] BirgeRönnerfelt, M. \& Norman, E. (2015). Reflektion som arbetsutveckling.[Reflection as work development]. Stockholm: StiftelsenStockholmsStadsÄldrecentrum [Foundation of Stockholm City, Elderly center].

[5] Edebalk, P.G., Samuelsson, G., Ingvad, B. (1995). How Elderly People Rank-Order the Quality Characteristics of Home Services. Ageing and Society. Volume 15, Issue 1, pp.83-102.

[6] Ellström, E., Ekholm, B. \& Ellström, P-E. (2003). Verksamhetskultur och lärande. [Workingculture and learning] Lund: Studentlitteratur.

[7] Ellström, E., Ekholm, B. \& Ellström, P-E. (2008). Two types of learning environment: enabling and constraining.A study of care work. Journal of Workplace Learning, 2008, 20(2), 84-97.

[8] Hjalmarson, Ingrid (2014). Vem ska bestämma vad i hemtjänsten?[Who will decide what in home care?] Stockholm: [Report / Stockholm County Foundation: Elderly Center] Rapport/stiftelsenStockholmsläns Äldrecentrum 2014:2 
[9] Holmquist, M. (2015). Innovativutvärdering[Innovative evaluation, Paper for HSS 15 in Kalmar],Paper till HSS 15 i Kalmar, 2015-05-29.

[10] Kemmis, S. (1980). Action Research in Retrospect and Prospect. Paper presented to the Annual Meeting of the Australian Association for Research in Education in Sydney, Australia. Deakin: Deakin University

[11] Lindberg, M. (2016). Democratising innovation policy with gender - scientific participatory research. In Gunnarsson, Ewa et al: Action Research for Democracy. New York: Routledge.

[12] Nilsson, L. \& Herrman, M. (2012) Co-generative learning at the frontline of elderly care: options for fulltime work in the outermost reaches of the organization. Advances in Social Service Research Journal, Vol. 3 , no $1,187-200$.

[13] Socialstyrelsen (2006). [The National Board of Health and Welfare]. Social styrelsens föreskriftero challmännarådomlednings systemförkvalitetiverksamhetenlSoL, LVU, LVM och LSS [The National Board of Health and Welfare regulations and general advice on management systems for quality in operations according to SoL, LVU, LVM och LSS] (SOFS 2006:11). p. 453.

[14] Socialstyrelsen (2008). [The National Board of Health and Welfare. I den äldrestjänstäldreassistent ettframtidsyrke. ]. [In the Elder's Service Elderly Assistant - a Future Profession](SOU 2008:126). Stockholm: EditaSverige AB.

[15] Socialstyrelsen (2011). [National Board of Health and Welfare]. Grundläggande kunskaper hos persona som arbetar $i$ socialtjänstens omsorg om äldre.[Basic knowledge of people who work in the Social Services' care for the elderly]. http://www.socialstyrelsen.se/Lists/Artikelkatalog/Attachments/18501/20 11-11-28.pdf

[16] Socialstyrelsen (2012). [The National Board of Health and Welfare]. Nationell värdegrund för äldreomsorgen [National values for elderlycare]. http://socialstyrelsen.se/aldre/nationellvardegrund/[201610-13]

[17] Socialstyrelsen (2013). [The National Board of Health and Welfare]. Värdegrundeni social tjänstensomsorgomäldre. [The value system of the social service's care for the elderly.] SOFS 2012:13 (S). Allmännaråd.[General recommendations]. http://www.socialstyrelsen.se/publikationer2012/2012-2-20/

[18] Stigendal, M. (2011). "det handlar om något större” : kunskaper om ungdomars möte med sin stad. Följeforskningom New City. [It's about something bigger ": knowledge of young people's meeting with their city. Follow-up research on New City]. Malmö: Malmö University Publications in Urban Studies (MAPIUS);7

[19] Szebehely, M. (2011). Insatser för äldre och funktionshindrade i privat regi. [Private interventions for the elderly and the disabled] I: Hartman, L. (ed.). Konkurrensens konsekvenser. Vad händer med svensk välfärd? [The consequencesofcompetition. What is happening to Swedish welfare?]Stockholm: SNS Förlag.

[20] Svensson et al (2002) Interaktiv forskning - för utveckling av teori och praktik [Interactive research - for the developmentoftheory and practice]. Stockholm. Arbetslivsinstitutet. Arbetsliv i omvandling [Stockholm National Institute. Workinglife in transformation] 2002:7.

[21] Sörensdotter, R (2008). Omsorgsarbete i omvandling: Genus, klass och etnicitet inom hemtjänsten. [Caring in transition: Gender, class and ethnicity in home help].Stockholms universitet, Samhällsvetenskapliga fakulteten, Social antropologiska institutionen. [Stockholm University, Faculty of Social Sciences, Departmentof Social Anthropology.]

[22] Thorslund, M. (2010). Äldreomsorgens utmaningar - i dag och i framtiden. The challenges of elderly care - today and in the future. Stockholm: Karolinska Institute/Stockholm University: Aging research Center.

\section{AUTHOR's BIOGRAPHY}

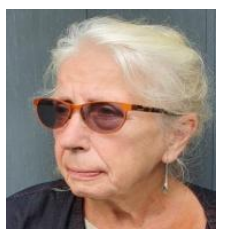

Margaretha Herrman is a senior associate Professor and Lena Nilsson, $\mathrm{PhD}$ is a senior associate Professor. They have both worked together in several projects on work integrated learning and their common research interest include projects concerning elderly care, home care and ageism with a focus on structural conditions and society's view on aging.

Citation: Margaretha Herrman, Lena Nilsson. "Learning Collaboration in Home Care Service" International Journal of Humanities Social Sciences and Education (IJHSSE), vol 7, no. 7, 2020, pp. 33-39. doi: http://dx.doi.org/10.20431/2349-0381.0707004.

Copyright: (C) 2020 Authors. This is an open-access article distributed under the terms of the Creative Commons Attribution License, which permits unrestricted use, distribution, and reproduction in any medium, provided the original author and source are credited. 